\title{
Aproximações entre charges e memes em ambientes digitais ${ }^{1}$ Approaches between political cartoons and memes in digital environments
}

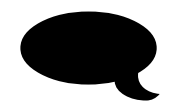

Rafaella Carvalho Barbosa²
Universidade Federal de São Paulo, Guarulhos, Brasil

Resumo: Propõe-se a investigar uma mistura encontrada entre charges e memes no meio digital. $\mathrm{O}$ objeto é composto por publicações feitas em quatro sites diferentes com a intenção de compilar produções de humor criadas por usuários da internet, chamadas de memes, sobre o processo de afastamento da ex-presidente Dilma Rousseff, que ocorreu em meados de 2016. Com a observação dessas publicações, foi possível perceber que apesar de os autores classificarem as imagens selecionadas apenas como memes, seja no título, ou no corpo dos textos introdutórios, algumas charges fazem parte das compilações sem distinção dos dois gêneros. A fundamentação teórica é composta pela definição do que são charges por Romualdo (2000), Cagnin (1975) e Ramos (2009); e o que são (ou não são) memes por Dawkins (1976), Horta (2015) e Celidonio (2016). Partindo do pressuposto de que os dois são gêneros diferentes, a análise foi feita com foco nos elementos que marcam uma influência das charges na construção do meme, um novo tipo de produção textual humorística que se popularizou junto com o crescimento do acesso à internet. Essa influência, então, pode justificar a aproximação dos dois no ambiente digital e pode causar a mistura encontrada nas publicações analisadas.

Palavras-chave: Memes. Charges. Ambiente Digital.

Abstract: Proposes to research the mix between political cartoons and memes in the digital environment. The object is composed by publications in four different sites, aiming compiling humor productions created by internet users, called as memes, about the impeachment process of ex-president Dilma Roussef, occurred in 2016. By the observations of those publications, it was possible to perceive that, notwithstanding authors classify the selected images only as memes, both in the titles or in the introductory texts, some political cartoons are in the compilations without any separation of the two genders. The theoretical foundation is composed by the definitions of political cartoons by Romualdo (2000), Cagnin (1975) and Ramos (2016); as well as the definitions regarding to what memes are (or are not) by Dawkins (1976), Horta (2015) and Celidonio (2016). Beginning with the presupposition that the two genders are different, the analysis focused on the elements that fix the influence of political cartoons in the construction of the memes, a new kind of humoristic textual production that has been popularized with the growth of the internet access. That influence can justify, then, the approximation between both in the digital environment and can give birth to the mix found in the analyzed samples.

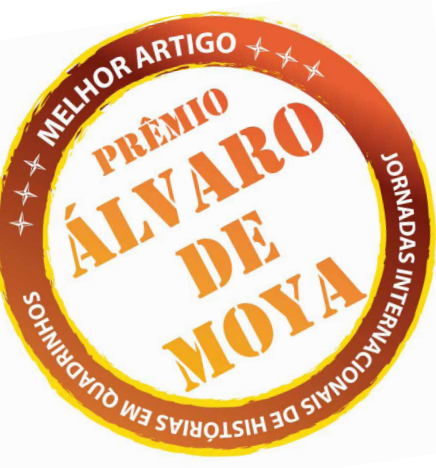

1.Trabalho vencedor do Prêmio Álvaro de Moya de Incentivo à Pesquisa em Quadrinhos de 2019, concedido ao melhor trabalho apresentado às 5 as Jornadas Internacionais de Histórias em Quadrinhos, realizadas de 22 a 24 de agosto de 2018. O prêmio é destinado a reconhecer e valorizar os pesquisadores que participam a cada edição desse evento científico.

2. Bacharel em Letras Português e Inglês - pela Universidade Federal de São Paulo. $O$ artigo constitui resultado parcial de seu projeto de iniciação à pesquisa intitulado Memes e suas relações com as charges no meio virtual. Email: rafaellacrvlh@gmail.com.

Keywords Memes. Political cartoons. Digital environment. 
3. http://agenciabrasil.ebc. com.br/geral/noticia/2016-12/ ibge-celular-se-consolidacomo-o-principal-meio-deacessointernet-no-brasil.

\section{Introdução}

A tecnologia que permite o acesso à internet está nas palmas das mãos das pessoas em todo o país. Segundo pesquisa do IBGE feita em 2016³ , nas últimas décadas, mais da metade da população de 10 anos ou mais passou a ter acesso à internet, além de o smartphone ter se tornado o principal meio de acesso, ou seja, um único aparelho que cabe em um bolso é usado como porta para um mundo infinito de informaçóes. $\mathrm{O}$ crescente uso de ferramentas digitais, principalmente por meio de redes sociais como Blogs, Facebook, Twitter, Instagram, entre outros, possibilita que os usuários também sejam criadores de conteúdo, tirando das mãos dos veículos tradicionais de comunicação, como jornais impressos e a televisão, o monopólio do compartilhamento de informações em larga escala.

O crescimento desse ambiente tornou favorável o surgimento de novas maneiras de apropriação dos textos, principalmente os humorísticos, que são variados e fazem parte significante do dia a dia dos usuários da internet. As esferas comunicativas humanas, descritas por Bakhtin (2003), estão ainda mais complexas e em constante mudança. Há, dentro do ambiente digital, gêneros que se apropriam de outros e de si mesmos para atender aos propósitos comunicativos em constante mudança das interações por meio das ferramentas digitais.

Um exemplo desses gêneros é o meme, que apresenta pontos de contato com diversos outros tipos de produções do ambiente digital ou anteriores a ele, como os quadrinhos e, mais especificamente, as charges. A relação das charges com os jornais, por sua vez, acabou mudando por causa de sua inserção no meio digital, pois suas publicações se tornaram mais constantes e afastadas dos grandes veículos da mídia. Além de sofrerem tais mudanças, as charges exercem influência nos mecanismos usados para a produção do humor crítico no ambiente digital, o que pode ser observado em memes feitos em contextos de mudanças políticas, como em 2016, quando houve um movimento para afastar Dilma Rousseff de seu cargo da presidência da república. Entre os resultados de busca no Google com as palavras-chave "os melhores memes do impeachment", quatro publicações de sites diferentes chamaram a atenção por serem compilações de imagens variadas, inclusive charges, com apenas uma classificação explícita: a de meme. Partimos da hipótese de que as charges e os memes selecionados pelos autores dessas publicações estão misturados porque existem pontos em comum nos seus mecanismos de produção, principalmente nas relações intertextuais que constituem o humor desses textos.

\section{1 - Charges}

A autonomia da linguagem dos quadrinhos é descrita por Cagnin (1975) como quadrinhidade, ou seja, um conjunto de características presentes nesses textos que os distinguem de outras manifestações visuais ou verbais. Para o autor, é importante que os quadrinhos sejam estudados a partir desses elementos singulares que formam as cadeias narrativas dessas produções. Segundo esse autor,

O advento da fotografia e posteriormente do cinema despertou um interesse sempre crescente pela imagem, submetida desde então a profundas reflexões filosóficas. Os quadrinhos, coetâneos do cinema, sempre foram relegados a uma posição inferior, ao desprezo, até que, por obra e graça de estudiosos franceses e italianos, foram postos sob o foco destas reflexões. Escritores, moralistas, artistas, psicólogos, sociólogos, todos agora estudam essa literatura feita de imagens fixas." (CAGNIN, 1975, p. 15)

A literatura de imagens fixas descrita 
por Cagnin (1975) não é apenas constituída por elementos pictóricos ligados ao acaso, sem um objetivo. Ramos (2009, p. 16) afirma, assim, que os quadrinhos possuem uma "linguagem autônoma, que usa mecanismos próprios para representar os elementos narrativos", linguagem autônoma essa que é relevante para as análises dos gêneros dos quadrinhos como um todo. Portanto, a charge é um tipo de produção textual que se enquadra como um dos gêneros dos quadrinhos, e, então, também deve ser estudada e analisada como tal.

Para o autor, os quadrinhos podem ser considerados como um grande rótulo (um hipergênero) que agrega diversos gêneros. Essas subdivisões, compostas por tipos relativamente estáveis de enunciados, como descreve Bakhtin (2003), compartilham mecanismos narrativos e de composição, por isso podem ser estudados sob uma mesma visão.

Romualdo (2000) define charge como um texto visual acompanhado ou não de um código verbal (que completa ou não a mensagem que o autor procura passar ao leitor), com uma característica básica: o humor, que estimula a ativação do conhecimento prévio dos leitores para a sua compreensão. A conversa entre as diferentes semioses que fazem parte da composição da charge também é importante: os desenhos e os textos verbais se completam.

Como descrito por Romualdo (2000), as charges tiveram sua origem em jornais impressos com a função de não apenas reproduzir, mas construir de forma ficcional acontecimentos das manchetes ou dos cadernos políticos, ou seja, o diálogo com o atual por meio da intertextualidade faz parte de sua essência.

Romualdo (2000) explica que o leitor recupera informações das notícias diárias ou de dias anteriores à publicação de determinada charge para entendêla, ou seja, a produção de um texto está diretamente ligada à retomada de um anterior, processo que define a intertextualidade, em um processo no qual "todo texto é um mosaico de outros textos" (CAVALCANTE, 2012. p. 146).

A relação da charge com o jornal impresso mudou com o crescimento do uso de meios virtuais para a obtenção e compartilhamento de informações. Ao passo que as notícias digitais se tornaram mais acessíveis, o jornal impresso, ainda que presente nas bancas, ficou menos popular, o que fez os grandes agentes da comunicação se voltarem para os portais on-line e adaptarem seus conteúdos a um novo contexto.

As charges, então, também foram inseridas na internet e se espalharam facilmente. Sem perderem as características do jornal impresso descritas por Romualdo (2000), essas produções receberam funções além de dialogar com as manchetes, sejam do mesmo dia ou de dias anteriores à sua publicação. A ampliação dos assuntos abordados nas charges para questões fora das primeiras páginas dos jornais impressos foi facilitada com a presença dos chargistas em redes sociais, ou seja, nos meios em que as opiniões podem ser livres e publicadas a qualquer momento.

Agora, as notícias, mesmo após a publicação na internet, podem ser constantemente atualizadas com novas informações, assim como as charges podem ser editadas para caberem em novos contextos. Ainda assim, como é descrito por Romualdo (2000), a textualidade das charges se dá por meio da interação entre o espaço e a forma em que são publicadas, com ironia e com diálogo crítico sobre, principalmente, eventos políticos.

Uma busca por charges publicadas na internet que são produzidas a partir da intertextualidade com notícias nos levou ao processo de afastamento de Dilma Rousseff de seu cargo como presidente da república, e, consequentemente, às publicações do chargista Carlos Latuff em sua conta do Instagram ${ }^{4}$.

Mostrando um posicionamento político sobre a votação da Câmara que ocorreu no dia 17 de Abril de 2016, o

\section{4. https://www.instagram.com/} carloslatuff/. 
chargista fez uma série de publicações que se relacionam de maneira intertextual com as notícias sobre o ocorrido. Essas notícias foram veiculadas pelos portais de notícias e atualizadas conforme a votação ocorria, como no exemplo a seguir (figura 1):

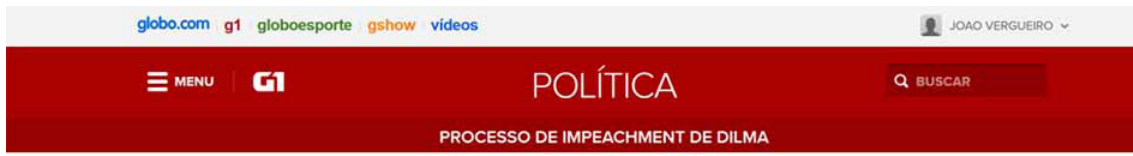

\section{Câmara aprova prosseguimento do processo de impeachment no Senado $\mid \begin{aligned} & \text { Processo de } \\ & \text { mpeachment de Dilma }\end{aligned}$}

Impeachment recebeu 367 votos favoráveis e 137 contrários.
Processo seguirá para o Senado, que decidirá se julga denúncia

Figura 1-G1: Câmara aprova o prosseguimento do processo de impeachment no senado. Fonte: http://g1.globo.com/politica/processo-de-impeachment-de-dilma/noticia/2016/04/ camara-aprovaprosseguimento-do-processo-de-impeachment-no-senado. Acesso em: 09 Set. 2018.

É possível perceber que as charges de de sua conta pessoal e usadas até mesmo Latuff como um todo dialogam com notícias por órgãos conhecidos nacionalmente e que de eventos políticos mundiais e, nesse caso, poderiam ser vistas em diversos sites, retiradas concordam com suas opiniões, como pode ser visto nas figuras 2 e 3 .
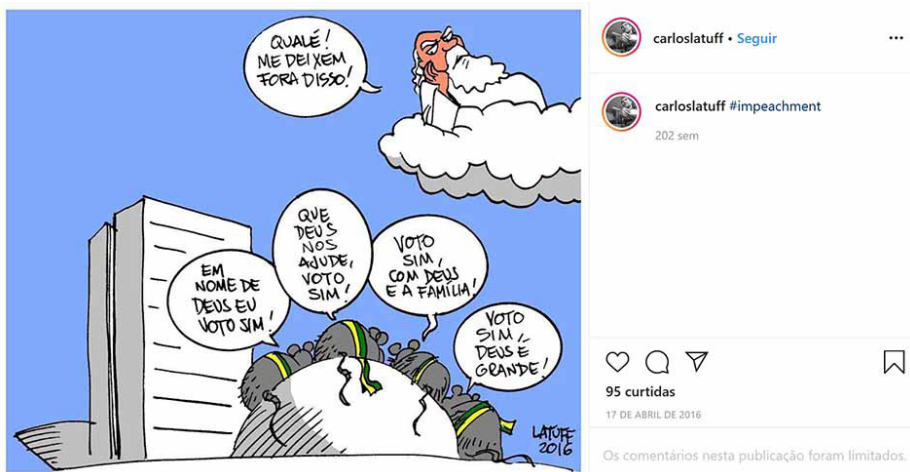

Figura 2 - Charge de Latuff publicada no Instagram em 17 de abril de 2016. Fonte: https://www.instagram.com/p/BEUS3GdgLxy/?taken-by=carloslatuff. Acesso em: 09 Set. 2018.

\section{A volta da religião, família e Deus contra a corrupção}

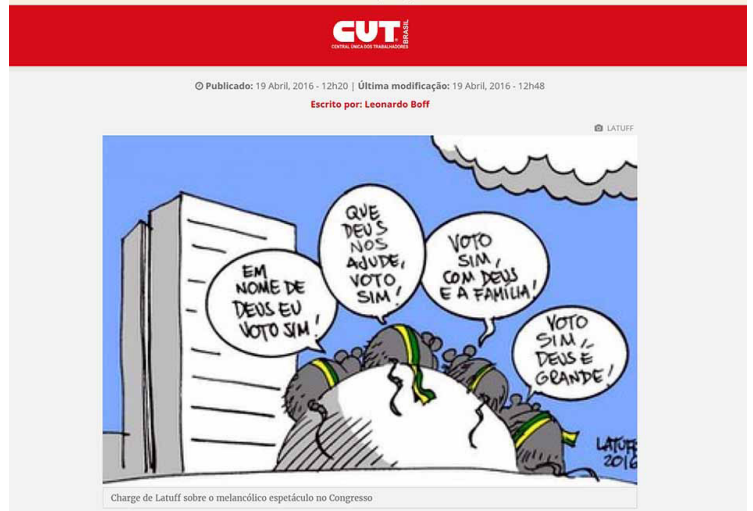

Figura 3 - Publicação no site da CUT que utiliza a charge de Latuff. Fonte: https://www.cut.org.br/noticias/o-golpe-e-a-volta-reacionaria-da-religiao- familia-e-de-deus-contra-acorrupcao-17ed. Acesso em: 9 Set. 2018. 
Retiradas de sua plataforma original, o Instagram, essas charges "viajaram" pela internet. A autoria, apesar da assinatura de Latuff, ficou escondida pela marca dágua de terceiros. Além disso, sua "etiqueta" de charge foi trocada pela de "meme", como no exemplo a seguir (figura 4), retirado do site "Não Entre
Aki". Como uma espécie de "9gag" brasileiro, nessa plataforma é possível que os usuários publiquem imagens (chamadas de memes) com o intuito de chamar atenção para assuntos diversos de uma maneira humorística. A partir disso, um questionamento foi levantado: o que é um meme, afinal?

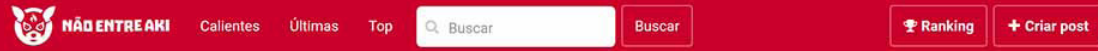

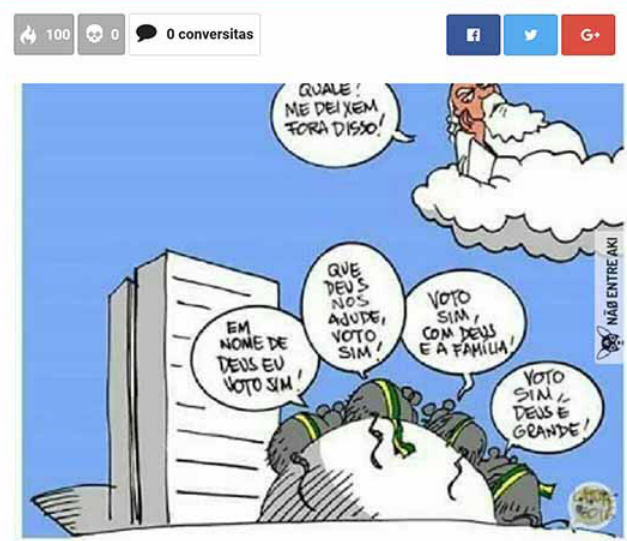

Figura 4 - Publicação no site "Não Entre Aki" que usa a charge de Latuff.

Fonte: http://www.naoentreaki.com.br/16403676-.htm. Acesso em: 09 Set. 2018.

\section{2-Memes}

O termo memeé fonte de muitas dúvidas e discussões por ter sua popularidade difundida em um ambiente que permite modificações de tudo a todo instante: a internet. Com sua origem na obra $O$ gene egoista, de Richard Dawkins, de 1976, o meme é estudado sob a luz da teoria da Mimética: um estudo baseado em teorias da genética de Darwin com o propósito de colocar em foco a cultura e como ela é perpetuada de geração em geração.

Para Dawkins (1976), o meme é uma unidade mínima da memória (assim como o gene é para a genética) composta por partes da cultura de um povo, como ideias, costumes e valores que são replicados pelo processo da imitação, moldando o comportamento humano e perpetuando esses moldes ao longo do tempo.

O meme da internet considerado neste estudo parte da definição de Dawkins (1976) de que se trata de uma produção cultural viva, em constante mudança e capaz de ser replicada facilmente, mas com aloumas diferenças trazidas pelo contexto digital e pela adaptação do termo a esse meio. Em primeiro lugar, entre o meme de Dawkins (1976) e o meme da internet como conhecemos hoje, há uma mudança na concepção do sujeito, pois, no processo de imitação, ele deixa de ser passivo enquanto absorve e replica inconscientemente "pedacinhos" de cultura que "viajam" espontaneamente de geração em geração. Quando o termo foi aplicado no meio digital, passou a englobar ações conscientes, ligadas à perpetuação de ideias por meio de produções textuais de diversos tipos que se apropriam de outras e de si mesmas para comunicar e, principalmente, ironizar de maneira humorística o presente.

Outra mudança levada ao termo meme pelo contexto digital está na sua sobrevivência. Enquanto o sucesso do meme de Dawkins (1976) era dado por sua longevidade sem mudanças no passar de geraçóes, o meme da internet precisa ser modificado a todo instante para continuar relevante, o que faz o fenômeno ser acelerado para um piscar de olhos, como descrito por Shifman (2014). A expansão de uso do vocábulo "meme" como descrito por Horta (2015), portanto, estende os estudos de Mimética de Dawkins (1976) a um novo 
mundo que nem mesmo o autor considerou quando publicou sua obra:

(...) Expandimos, assim, a proposta inicial de Dawkins, mostrando que o termo "meme" incorporou e passou a representar também o sentido de "meme da internet", que, apesar de ser um fenômeno cultural que poderíamos entender dentro da lógica de Dawkins, faz parte de um contexto específico, o da internet como meio de comunicação. (HORTA, 2015 p. 46)

O meme da internet, mais conhecido apenas por meme, se apropria de situaçóes cotidianas, fatos históricos, políticos, enfim, qualquer evento com o qual seja possível fazer humor. Para a propagação do meme, é fundamental que ocorra um "redesign", processo descrito por Celidonio (2016) que se dá pela alteração de alguns aspectos dos textos com pelo menos uma característica do replicador original, seja essa característica algo da materialidade do texto ou da ideia que o originou, em um processo de retomada de um texto anterior, ou seja, um processo intertextual.

Através de uma imagem ou idéia que se espalha de forma viral na web, um meme, fruto da apropriação feita por diferentes usuários, é formado pela combinação de permanência de um elemento replicador original e pela mutação deste elemento, seja através de um "redesign" ou de uma legenda, desde que o faça tomar forma de um novo signo. (CELIDONIO, 2016.p. 130)

Os exemplos das figuras 5, 6, 7 e 8 foram retirados de uma matéria do portal TecMundo, força kkkkkkkk

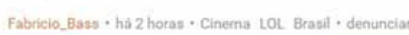

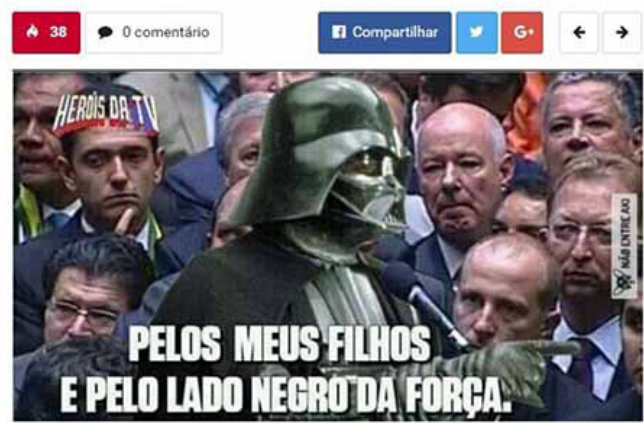

meu voto é sim

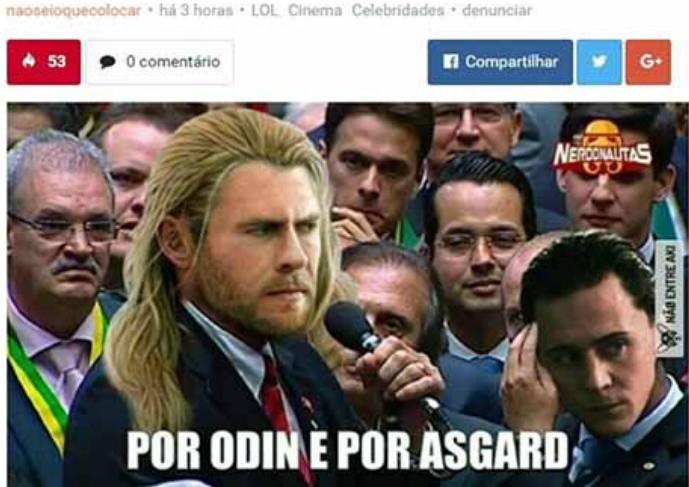

kkkk

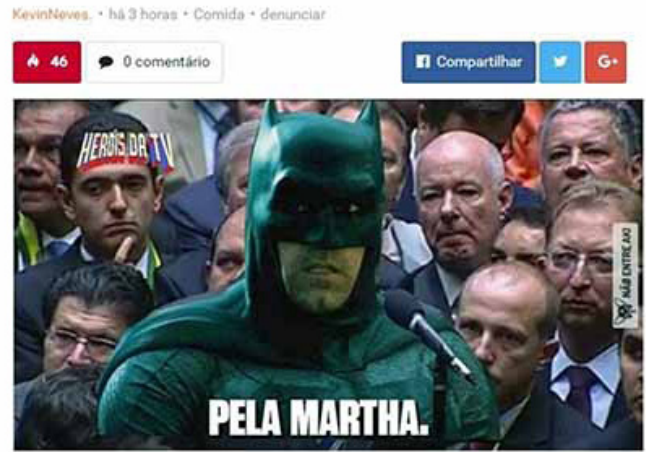

Ela tbm pode kkkkk

Blackthawk - hai 2 horas - Bizarro Brasil PQP - denunciar

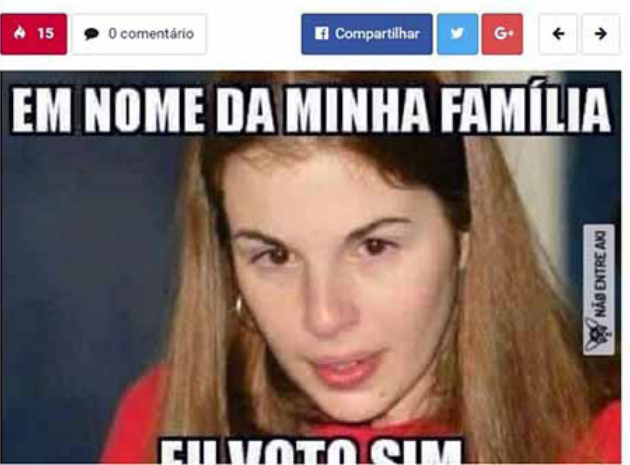

Figura 5, 6, 7 e 8 - Memes que satirizam a votação do Impeachment de Dilma Rousseff. Fonte: https://www.tecmundo.com.br/memes/103782-melhores-memes-votacao- impeachment-dilma.htm. Acesso em: 09 Set. 2018. 
site no qual são publicados artigos sobre tecnologia e notícias sobre o meio virtual, escrita por Eduardo Harada na sessão "Cultura Geek", intitulada "Os melhores memes sobre a votação de impeachment da Dilma”. Com o intuito de fazer uma compilação de memes sobre esse determinado contexto histórico, o autor fez um apanhadodeimagens publicadas no site "Não Entre Aki", citado anteriormente, que foram criadas para ironizar a votação na Câmara dos Deputados, em que as frases dos presentes no local ficaram famosas ${ }^{5}$ por sempre citarem terceiros, familiares, ou até mesmo Deus, antes do "Sim", ou do "Não, para a continuação do processo de afastamento de Dilma Rousseff.

É clara a relação intertextual desses memes com o evento em si, uma vez que foram feitos com montagens e legendas que modificam as frases repetidas exaustivamente durante a votação na Câmara. O humor está ligado com o fato de que essas personalidades ficcionais ou não - Darth Vader, Batman, Thor e Suzane von Richthofen - possuem problemas familiares que são conhecidos nacionalmente ou internacionalmente por motivos diversos.

O replicador original é incerto nesse caso, pois não se sabe quais foram as inspirações dos autores desses memes, mas a ideia a qual fazem alusão é facilmente identificada, além de ser possível perceber certa ironia às falas dos deputados presentes na votação, que foi acompanhada de perto pela população por meio da televisão e por portais on-line $e^{6}$.

No processo de "fabricação" dos memes, essas produções são adaptadas a contextos diferentes com elementos de diversos gêneros, inclusive dos quadrinhos. Entre eles, nos casos citados, estão o diálogo com o atual e o cunho crítico dado pela intertextualidade com um contexto político muito presente em charges.

A apropriação de elementos de outros gêneros dá ao meme da internet uma característica instável, pois pode assumir uma variedade de formas com apenas uma característica em comum: a subversão de um replicador original, como nomeado por Celidonio (2016), que, a partir de marcas sutis ou não, pode ser percebido na nova produção.

Hoje em dia, os memes circulam livremente em todas as esferas de comunicação, característica ligada ao fato de a internet ser um universo em que elas se sobrepõem. Isso permite que o meme assuma formatos diversos, entre eles, vídeos, frases, capturas de tela de posts em redes sociais e muitos outros.

A internet suscita mudanças de maneira acelerada nessas esferas, o que, segundo Marcuschi (2010), criou novas possibilidades de produção textual adaptadas a esse novo contexto, as quais ele nomeia como gêneros emergentes: formas de interação que se apropriam de gêneros anteriores ao meio digital e adaptam seus elementos às novas ferramentas de comunicação.

O meme, portanto, pode ser considerado um gênero emergente por ser formado pela influência de diversos gêneros, como um ser que pode englobar tudo em uma brincadeira perpetuada pelas diversas modificações que os usuários da internet são capazes de criar e compartilhar principalmente pelas redes sociais.

\section{3 - Análise}

A análise é composta por quatro publicações de sites diferentes sobre o mesmo tema: o processo de afastamento de Dilma Rousseff que ocorreu em meados de 2016. Essas publicações chamaram a atenção por uma série de características em comum.

Em primeiro lugar, foi possível perceber que os memes presentes nas matérias são caracterizados pelos autores como produções de humor feitas por usuários de redes sociais variadas. Além disso, os títulos e os corpos dos textos das matérias apresentam apenas a palavra meme para descrever as imagens
5. https://www1.folha.uol.com $\mathrm{br} /$ poder/2016/04/1762082 veja-frases-dos-deputadosdurante-a-votacao-doimpeachment.

6. https://m.folha.uol.com.br/ ilustrada/2016/05/1771102votacoes-do-impeachmentmultiplicam-audiencia-das-tvscamarae-senado 
7.http://istoe.com.br/humorem-tempos-de-crise.

8. http://blogs.jornaldaparaiba. com.br/suetoni/2016/04/18/ em-nome-dos-meus-filhosdigo-sim-para-os-memessobreimpeachment.

9. https://revistagalileu. globo.com/Sociedade/ noticia/2016/08/o-processode-impeachment-de-dilmarousseff-atraves-dosmemes.

10. https://www.tecmundo. com.br/memes/103782melhores-memes-votacaoimpeachment-dilma. selecionadas, ou seja, apesar da presença de mais de um gênero, não há distinção explícita entre eles. Uma terceira característica é o fato de serem publicações com grande número de compartilhamentos e reações de usuários da internet.

A quantidade de imagens nas publicações foi mapeada com o intuito de classificarmos as imagens entre memes e charges. Entre 85 imagens, 6 são charges e 79

\begin{tabular}{|l|c|c|}
\hline Site & $\mathbf{N}^{\circ}$ charges & $\mathbf{N}^{\circ}$ memes \\
\hline Isto $\dot{E}^{7}$ & 2 & 5 \\
\hline Jornal da Paraíba & & 1 \\
\hline Revista Galileu & 1 & 17 \\
\hline TecMundo $^{10}$ & 1 & 50 \\
\hline Total & 2 & 79 \\
\hline
\end{tabular}

Tabela 1 - Quantidades de charges e memes nas compilações de memes de quatro sites. Fonte: Sites da internet

são memes (Tabela 1).

Com o levantamento de dados, foi possível perceber que as imagens foram classificadas apenas como memes por uma característica principal: a intertextualidade. Os exemplos a seguir (figuras 9 e 10), mostram que o diálogo com o atual está presente em ambos os gêneros, apesar de existirem diferenças que os afastam.

O humor do meme, à esquerda, está presente na relação da imagem com a parte verbal, além da intertextualidade com o contexto da crise política meados de 2016. Ao ler "Dilma manipulando as massas", é inesperado que "massas" se refira aos alimentos dessa categoria, pois espera-se que

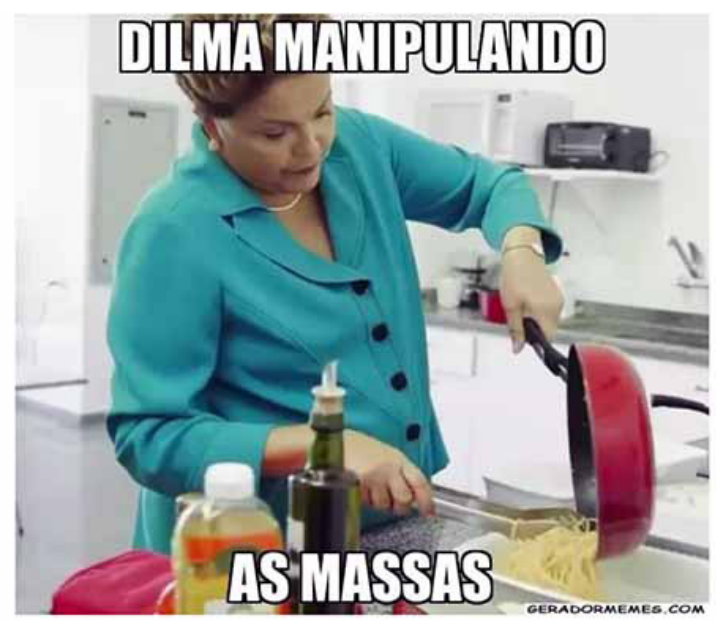

O destino vem a tricot...

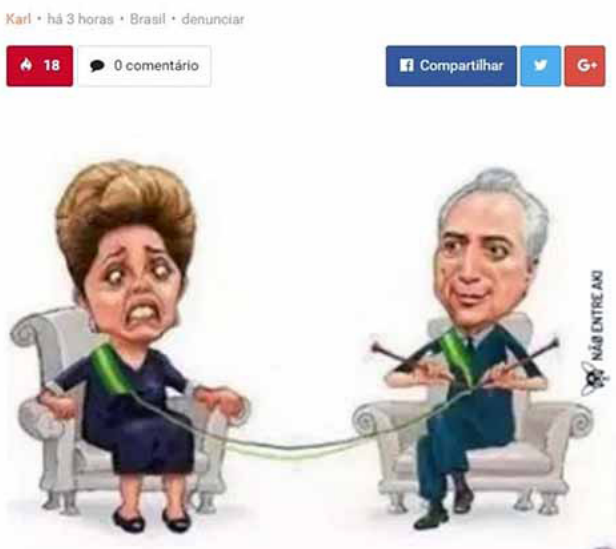

Figura 9 e 10 - Memes sobre impeachment de Dilma Roussef Fonte: https://revistagalileu.globo.com/Sociedade/noticia/2016/08/o-processo-de-impeachmentdedilma-rousseff-atraves-dos-memes.html e https://www.tecmundo.com.br/memes/103782-melhoresmemes-votacao-impeachmentdilma.html. Acesso em: 12 jul. 2018.

esse termo se refira à "população". A charge, à direita, apesar de não ter uma parte verbal, também utiliza a imagem de Dilma, e é nesse ponto em que a intertextualidade existe: na caricatura, tanto de Dilma, quanto de Temer.
Apesar de terem sido classificadas como memes, as imagens são diferentes em suas composições: o meme é uma montagem de Dilma Rousseff cozinhando com uma legenda que provoca o humor. A 
charge, por sua vez, é feita com caricaturas de Michel Temer e Dilma Rousseff. O mesmo acontece nos exemplos constantes das figuras 11 e 12 :

O meme do Michael Jackson comendo pipoca é utilizado como uma reação a polêmicas ou assuntos importantes que são amplamente veiculados nas redes sociais ou pela mídia. Ele pode ser encontrado com diversas legendas e formatos, mas nesse caso, faz referência ao impeachment com a frase "traz a pipoca que tá tendo muito impeachment".

A charge, de Latuff já citada anteriormente, também faz referência ao mesmo contexto por meio $\mathrm{da}$ intertextualidade, mas suas características, como o uso de desenho e balóes de fala, são bem diferentes das utilizadas pelo criador do meme do Michael Jackson, que utiliza a legenda e uma foto.
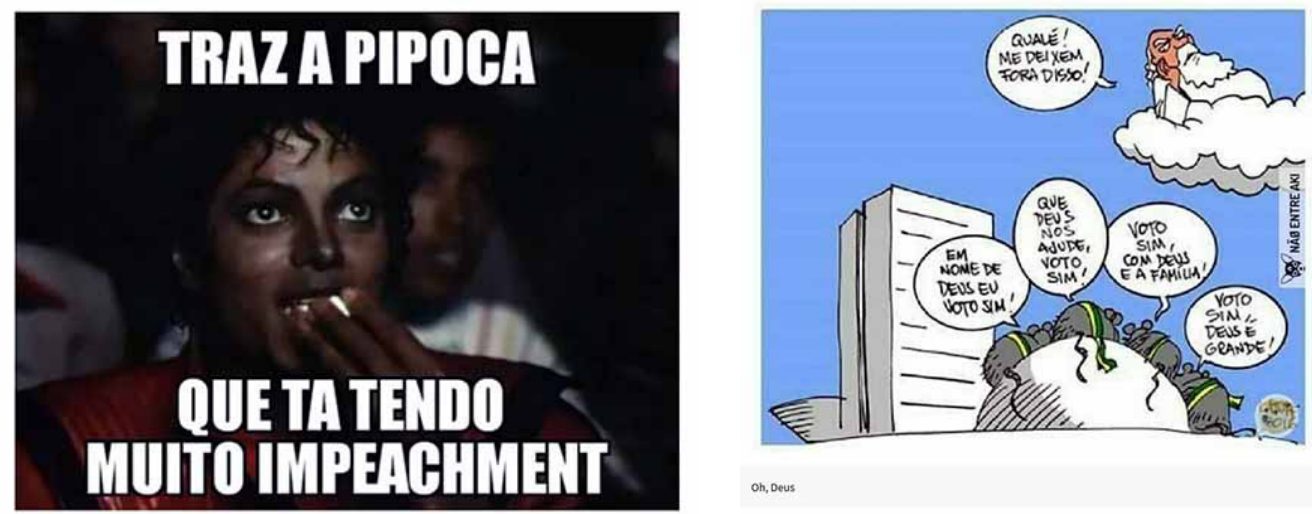

Figura 11 e 12 - Michael Jackson comendo pipoca e charge de Latuff.

Fonte: https://revistagalileu.globo.com/Sociedade/noticia/2016/08/o-processo-de-impeachment-de-dilma-rousseff-atraves-dos-memes.html e https://www.tecmundo.com.br/memes/103782melhores-memesvotacao-impeachment-dilma. Acesso em: 12 jun. 2018.

\section{Considerações finais}

Esta pesquisa está longe de esgotar as relações entre os quadrinhos, nesse caso as charges e os memes. Nota-se, pela análise de algumas das imagens presentes em quatro publicações diferentes, que a zona nebulosa encontrada entre esses gêneros em ambientes digitais é frutífera para diversos tipos de análises, principalmente quando são colocados lado a lado em um mesmo contexto, uma vez que apesar as diferenças nas composições das imagens, a intertextualidade os aproxima como um recurso utilizado para a construção de um humor que se fundamenta em pilares parecidos.

\section{Referências}

BAKHTIN, Mikhail. Os gêneros do discurso. In: BAKHTIN, Mikhail. Estética da criação verbal. São Paulo: Martins Fontes,
2003. p. 277-328.

BOFF, Leonardo. A volta da religião, família e Deus contra a corrupção. CUT - Central Única dos Trabalhadores [site]. Disponível em: https://www.cut.org.br/ noticias/o-golpe-e-a-volta-reacionariada-religiao-familia-e-de-deus-contra-acorrupcao-bb8e. Acesso em: 12 jun. 2018.

CAGNIN, Antonio Luiz. Os quadrinhos. São Paulo: Ática, 1975.

CAVALCANTE, Mônica Magalhães. Os sentidos do texto. São Paulo: Contexto, 2012. CELIDONIO, Bruno. Adaptação cultural e ressignificação de memes: um estudo teórico. Tematica, NAMID/UFPB, ano XII, jan. 2016. Disponível em: http:// periodicos.ufpb.br/index.php/tematica. Acesso em: 17 ago. 2018.

DAWKINS, Richard. O gene egoísta. São Paulo: Companhia das Letras, 2007.

HARADA, Eduardo. Os melhores 
memes sobre a votação de impeachment da Dilma. TecMundo [site] Publicado em 18 abril 2016. Disponível em: https:// www.tecmundo.com.br/memes/103782melhores-memes-votacao-impeachmentdilma.htm. Acesso em: 12 jun. 2018.

HORTA, Natalia Botelho. O meme como linguagem da internet: uma perspectiva semiótica. 2015. 191 f. Dissertação (Mestrado em Comunicação) - Faculdade de Comunicação, Universidade de Brasilia, Brasilia, 2015. Disponível em: https://repositorio.unb. br/bitstream/10482/18420/1/2015 NataliaBotelhoHorta.pdf. Acesso em: 04 mar. 2020.

MARCUSCHI, Luis Antonio. Gêneros textuais emergentes no contexto da tecnologia digital. In: MARCUSCHI, Luís Antonio; XAVIER, Antonio Carlos. Hipertexto e gêneros digitais: novas formas de construção de sentido. 3. ed. 2. reimpr. São Paulo: Cortez, 2010. p. 13-67.

RAMOS, Paulo. A leitura dos quadrinhos. São Paulo: Ed. Contexto, 2009.

ROMUALDO, Edson Carlos. Charge jornalística: intertextualidade e polifonia: um projeto das charges da Folha de $\mathrm{S}$. Paulo. Maringá, PR: Eduem, 2000.

SHIFMAN, Limor. Memes in digital culture. Cambridge, MA: MIT Press, 2014. 